\title{
When Teachers Were Farmers: Teachers' Allotted Farms and the Funding of Mass Schooling, 1838-1900
}

\author{
Johannes Westberg
}

\begin{abstract}
What were teachers' allotted farms, and what were they for? This study aims to answer these questions by examining these farms in nineteenth century Sweden, and their role in the expansion of the elementary school system in 1838-1900. Focusing on the allotted farms of the Sundsvall region, this article analyses how these farms provided teachers with fields and meadows, as well as outhouses such as cowsheds, bakehouses and cellars. This article argues that these farms made schooling more affordable for the school districts, primarily in the first two decades after the Elementary School Act of 1842. Allotted farms were often inexpensive to acquire and maintain, not least owing to the agricultural and maintenance work that the teachers carried out, and yielded an annual return that reduced the taxation needed to operate the school districts. This, in turn, facilitated the expansion of schooling.
\end{abstract}

Keywords

teachers, allotted farms, mass schooling, schools, school finance

Since the expansion of schooling in the eighteenth and nineteenth centuries, its history has aroused interest among researchers and educators. Consequently, abundant research has dealt with such issues as the politics of elementary education, development of school subjects, professionalisation of teaching staff and functions of mass schooling in the emerging capitalist, industrial and urbanised society. ${ }^{1}$

There are, however, a number of areas that have received less attention. Despite

1 On the history of Swedish mass education, see e.g., Christina Florin, Kampen om katedern: Feminiserings- och professionaliseringsprocessen inom den svenska folkskolans lärarkåren 1860-1906 (Umeå: Almqvist \& Wiksell International, 1987); Magnus Hultén, Naturens kanon: Formering och förändring av innehållet $i$ folkskolans och grundskolans naturvetenskap 1842-2007 (Stockholm: Stockholms universitet, 2008); Ulla Johansson, Att skolas för hemmet: Trädgårdsskötsel, slöjd, huslig ekonomi och nykterhetsundervisning $i$ den svenska folkskolan 1842-1919 med exempel från Sköns församling (Umeå: Umeå universitet, 1987); Lars Petterson, Frihet, jämlikhet, egendom och Bentham: Utvecklingslinjer i svensk folkundervisning mellan feodalism och kapitalism, 1809-1860 (Uppsala: Almqvist \& Wiksell International, 1992); Inger Andersson, Läsning och skrivning: En analys av texter för den allmänna läs- och skrivundervisningen 1842-1982 (Umeå: Umeå universitet, 1986); and John Boli, New Citizens for a New Society: The Institutional Origins of Mass Schooling in Sweden (Oxford: Pergamon, 1989).

Johannes Westberg is Associate Professor in History at the Department of Education, Uppsala University, Sweden.

Email: johannes.westberg@edu.uu.se

In order to maintain the integrity of the peer-review process, associate editor Björn Norlin has mediated the contacts between the author (who is the principal editor of this issue) and the reviewers of this article. 
considerable efforts in this field of study, research exploring the social and economic conditions of the emerging systems of mass schooling is lacking. Among other issues, the teachers' allotted farms (lärarboställen) have not been subjected to a closer study. It is well known that, in the eighteenth and nineteenth centuries, teachers in Sweden and elsewhere were provided with housing and a plot of land, as part of their salary. ${ }^{2}$ For example, the Swedish Elementary School Act of 1842 (folkskolestadgan) stipulated inclusion in a teacher's salary of a "suitable dwelling" and summer grazing for a cow. ${ }^{3}$ However, the significance of this statement, as well as its practical implications, remains to be studied.

Thus, this article aims to bridge this gap in current knowledge and initiate a closer study of Swedish teachers' allotted farms by answering basic questions concerning these farms: what they consisted of, why they were established, what labour was required from the teacher and his household, and why the practice of allotting farms was marginalised in the last decades of the nineteenth century.

Using these matters as a point of departure, this article will primarily shed light on how the expanding system of elementary schooling (folkskoleväsendet) in Sweden was funded. We know that the corresponding school systems in Europe and elsewhere were funded at local level, primarily by local taxes in cash or in kind. Figures compiled from 15 countries reveal that local school districts funded on average 55-58 per cent of the school systems' total revenues in the 1870 s. ${ }^{4}$ But we know less about how schools were funded at the local level, and even less about the role of allotted farms in this respect. ${ }^{5}$ In addition, this article will provide insights into the living and working conditions of teachers during this early phase of elementary schooling. As will be apparent, school teachers of the time did more than just teach. ${ }^{6}$

The empirical basis of this study consists of teachers' allotted farms in the twel-

2 Gunilla Klose, Folkundervisningens finansiering före 1842 (Uppsala: SEC, Uppsala University, 2011), 172; Mary Jo Maynes, Schooling for the People: Comparative Local Studies of Schooling History in France and Germany, 1750-1850 (New York \& London: Holmes \& Meier, 1985), 40; C. R. Day, "The Rustic Man: The Rural Schoolmaster in Nineteenth-Century France," Comparative Studies in Society and History 25, no. 1 (1983), 44; Ingrid Brühwiler, Finanzierung des Bildungswesens um 1800 in der Helvetischen Republik. Darstellung verschiedener Akteure sowie deren Einflussfaktoren und Wirkungen auf die wirtschaftliche Grundlage der Schule anhand ausgewählter Gemeinden und Städte in der Helvetischen Republik (Luxembourg: Université du Luxembourg, 2012a), 73.

3 Swedish Code of Statutes (SFS) 1842:19, Section 4.

4 Peter Lindert, Growing public: Social Spending and Economic Growth since the Eighteenth Century Vol. 1 The Story (Cambridge: Cambridge University Press, 2004), 116-17.

5 Previous studies of the funding of mass education include Lindert (2004), Chapter 5; Carl F. Kaestle and Maris A. Vinovskis, Education and Social Change in Nineteenth-Century Massachusetts (Cambridge: Cambridge University Press, 1980), Chapter 7; David Mitch, "The Impact of Subsidies to Elementary Schooling on Enrolment Rates in Nineteenth-Century England," The Economic History Review 39, no. 3 (1986); Johannes Westberg, "Stimulus or Impediment? The Impact of Matching Grants on the Funding of Elementary Schools in Sweden during the Nineteenth Century," History of Education 41, no. 1 (2013), and literature cited in these works.

6 The living and working conditions of elementary school teachers are analysed in Day (1983); Susan B. Carter, "Occupational Segregation, Teachers' Wages, and American Economic Growth," The Journal of Economic History 46, no. 2 (1986); Florin (1987); Ingrid Brühwiler, "Teachers' Salaries in the Helvetic Republic, c. 1800," in History of Schooling: Politics and Local Practice, ed. Carla Aubry and Johannes Westberg (Frankfurt am Main: Peter Lang, 2012b); Erkko Anttila and Ari Väänänen, "Rural Schoolteachers and the Pressures of Community Life: Local and Cosmopolitan Coping Strategies in Mid-Twentieth-Century Finland," History of Education 42, no. 2 (2013), and literature cited in these works. 
ve rural school districts of the Sundsvall region, in the northern Swedish county of Västernorrland. The analysis starts in 1838, when the first allotted farm was acquired, and ends 62 years later at the turn of the century, thus covering the period in which elementary schooling was established in Sweden. The school districts of the Sundsvall region should not, of course, be perceived as average Swedish school districts, or as representing typical conditions in Sweden or elsewhere in Europe. As W. B. Stephens has pointed out, local and regional variations were so significant in the nineteenth century that "to talk of a national condition is to distort reality". ${ }^{7}$ But while the size and significance of teachers' allotted farms may vary, this study sheds light on issues regarding these farms and their relation to the school system that are fundamental, whether such farms were established in the Sundsvall region, Sweden or elsewhere. ${ }^{8}$

Since no archives or archival series on teachers' allotted farms remain, a wide range of source materials have been collected. As in other instances, when source materials are scarce, source pluralism is the method utilised. ${ }^{9}$ In this study, this means that I have sought to use as many kinds of source materials as possible, in order to be able to combine fragments from them. Thus, in addition to church archives, with their minutes and accounts, the documents consulted have mainly been cabinet acts (konseljakter) from the Ecclesiastical Office, documents at Lantmäteriet (the Swedish mapping, cadastral and land registration authority), and insurance contracts at the General Fire Insurance Board. Gabriel Thulin's survey of ecclesiastical allotted farms in six of Sweden's 24 counties has also been processed, along with a range of statistical data from the Ecclesiastical Office. ${ }^{10}$

\section{Ecclesiastical, military and civil allotted farms}

Until the nineteenth century, it was common practice for ecclesiastical, military or civil officials to receive free housing as a part of their salary. The official either received free housing in the form of an official residence (bostadsboställe) or was given the right to use adjoining buildings and land in an allotted farm (jordbrukarboställe). ${ }^{11}$

Allotted farms, which are the focus of this study, have a long history. With the establishment of parishes in Sweden from the Middle Ages, glebes (prästbord) were created to support parish priests. The practice of allotting farms became more widespread through the military allotment establishment (indelningsverket) that was set up in the eighteenth century to provide officers and soldiers with land as a part

7 W. B. Stephens, Education, Literacy and Society, 1830-70: The Geography of Diversity in Provincial England (Manchester: Manchester University Press, 1987), 2.

8 For further discussion about the importance of case studies, see Robert E. Stake, The Art of Case Study Research (Thousand Oaks, CA: Sage, 1995), 1-12; Sheilagh C. Ogilvie, A Bitter Living: Women, Markets, and Social Capital in Early Modern Germany (Oxford: Oxford University Press, 2003), 5-7.

9 This method is described in greater detail in Janken Myrdal, "Source Pluralism as a Method of Historical Research," in Historical Knowledge: In Quest of Theory, Method and Evidence, ed. Susanna Hellman and Marjatta Rahikainen (Newcastle upon Tyne: Cambridge Scholars Publishing, 2012), 155-89.

10 Gabriel Thulin, Redogörelse för de ecklesiastika boställena 6 vol. (Stockholm: s.n., 1904-29).

11 "Boställe", http://www.ne.se/lang/boställe, Nationalencyklopedin, August 4 2011; Björn Gerhardsson, "Boställen och karaktärshus. Något om boställssystemet i Örebro län och dess avveckling under 1800-talet," in Från bergslag och bondebygd 1997, ed. Lars Skoghäll (Örebro: Årsbok för Örebro läns hembygdsförbund, 1997), 69. 
of their salary. ${ }^{12}$ In addition, there were allotted farms for office holders in the civil service and people in a wide range of other occupations: from mine managers (bergmästare), company managers (chef), sheriffs (länsman), midwives, lighthouse keepers and physicians to gardeners. ${ }^{13}$

Regarding elementary school teachers, evidence suggests that in the western world in the eighteenth and nineteenth centuries, they were presented with land in lieu of cash salary to various degrees. In Baden (Southwest Germany), teachers were sometimes given the right to use communal lands in the late eighteenth century, while those working in the Swiss canton of Fribourg were, on occasion, provided with land plots, gardens or small vineyards. For French teachers, having a garden was still an important issue in the 1860 s. $^{14}$

In Sweden, the number and range of teachers' allotted farms increased in the early decades of the nineteenth century. The relative lateness of this phenomenon, in relation to allotted farms in other sectors, is largely explained by the fact that schooling was not established in Sweden until the late eighteenth and the early nineteenth century. Prior to that, home instruction was the dominant model of mass education. ${ }^{15}$ Teachers' allotted farms have also been linked to the transition from the itinerant teachers of the early schools to permanent schools that took place around this time. Since itinerant teachers moved from village to village, it was more convenient to pay them in housing and foodstuffs, than to present them with farms. However, once the number of schools increased, and many of these became permanent, allotted farms seemed a more attractive alternative. ${ }^{16}$

How many teachers' allotted farms were established, however, remains unknown. Existing records indicate that the number of parishes offering teachers a plot of land rose from seven in 1812 to 105 in 1839, in six of Sweden's 12 dioceses. ${ }^{17}$ Allotted farms probably became more numerous after the Elementary School Act of 1842. This Act required each of Sweden's 2,308 parishes (1839) to organise school districts, by themselves or in cooperation with other parishes, and each school district to esta-

12 Regarding the development of glebes in the Middle Ages and Early Modern period, see Elisabeth Gräslund Berg, Till prästens bruk och nytta: Jord till prästgårdar $i$ Sverige under medeltid och tidigmodern tid (Stockholm: Stockholms universitet, 2004), Chapter 4. The military's allotted farms are treated in e.g. Olle Cederlöf, "Indelningsverkets militära torp och boställen," Meddelande XXXVI Armémuseum 1975-76 (1976); Göran Ulväng, "Indelningsverkets militära boställen: Vad vet vi egentligen?"' Militärhistorisk tidskrift (2002); Fredrik Thisner, Indelta inkomster: En studie av det militära löneindelningsverket 1721-1833 (Uppsala: Acta Universitatis Upsaliensis, 2014).

13 On the existence of such allotted farms, see e.g., BiSOS U, Kommunernas fattigvård och finanser (1910), xii; Betänkande angående förändring av extra provinsialläkardistrikt ... (Stockholm: Nord. bokh., 1921), 86-87; Dan Thunman, Sveriges fyrplatser: En bebyggelsehistorisk dokumentation av f.d. bemannade fyrplatser anlagda under Lotsverkets tid (Norrköping \& Stockholm: Sjöfartsverket \& Riksantikvarieämbetet, 2000), 108-44. See also "Boställe", http://g3.spraakdata.gu.se/saob/, SAOB 9/8 2011.

14 Maynes (1985), 40; Day (1983), 44; Brühwiler (2012a), 73. There is also evidence of teachers' allotted farms in New Zealand; see Daily Southern Cross, Volume XXVIII, Issue 4596, 17 May 1872, 3.

15 This system of home instruction is described in Egil Johansson, "The History of Literacy in Sweden," in Understanding Literacy in its Historical Contexts: Socio-Cultural History and the Legacy of Egil Johansson, ed. Harvey J. Graff, Alison Mackinnon, Bengt Sandin and Ian Winchester (Lund: Nordic Academic Press, 2009).

16 Klose (2011), 172.

17 Klose (2011), 172. 
blish at least one school. ${ }^{18}$ The School Act was followed by a major expansion of the elementary school system that involved a rise in the number of teachers from 1,030 at permanent schools and 507 at ambulatory schools in 1839 to 7,045 (all teacher categories) in 1868 and 16,619 (all teacher categories) in $1900 .{ }^{19}$

In addition, the Elementary School Act of 1842 encouraged salary terms that provided teachers with land plots. According to the Act, every parish was to establish at least one school within five years, whose teacher, in addition to a salary in grain and cash, would be provided with housing and fuel, as well as summer grazing and winter feed for a cow. The School Act recommended making a plot available to the teacher, to supplement the teacher's income while providing extra scope for the education of the school children. ${ }^{20}$

There are also indications that provision of teachers' allotted farms was a matter of some national importance. The question of whether such farms were to be inspected by state officials was, for example, dealt with at the Diet of the Estates (standsriksdagen) in 1854, and the registers of Svensk Läraretidning (the Swedish teachers' magazine) show that the issue of allotted farms was recurrently debated until 1922. ${ }^{21}$ Furthermore, an analysis of the glebe lands in six counties shows that parts of these areas were assigned to teachers' allotted farms in five of these counties. Of the 98 transfers of land from glebes in 1838-1901, 38 involved land plots being assigned to teachers. ${ }^{22}$

Although the number of teachers' allotted farms, in all probability, increased in the first half of the nineteenth century, the significance of allotted farms and official residences was already starting to decline in other sectors. Military officers' allotted farms were greatly reduced in numbers after the wage regulation of 1833 , and abolished in 1875. Free housing for provincial doctors, i.e., medical officers with responsibility for large rural districts, was abolished in 1890. Similarly, in 1910, it was declared that parish priests were no longer to be supported by the glebes, although they still received free housing at the glebe house (prästgården), including its grounds and garden. ${ }^{23}$ In line with these reforms, the provision of teachers' allotted farms also soon came to an end. Within the elementary school system, free housing was abolished as a salary benefit under the wage settlement of $1937 .{ }^{24}$

Previous studies of ecclesiastical, military and civil allotted farms have brought to the fore a number of questions regarding various issues, such as the size, yield and

18 SFS 1842:19, Sections 1-2.

19 Klas Aquilonius, Svenska folkskolans historia: Del 2. Det svenska folkundervisningsväsendet 18091860 (Stockholm: Albert Bonniers förlag, 1942), 266; BiSOS P, Undervisningsväsendet (1868), xii; BiSOS P (1900), Table 2.

20 SFS 1842:19, Section 4.

21 Allm. Besv. och Ekon.-Utsk. Betänk. N:o 64, in Bihang till Riksdagens protokoll 1853-54, 8e samlingen; Svensk Läraretidning, Index for the volumes 1-51 (1882-1932). See also the articles "Lönevederlag medelst boställen" and "Syneförrättningar å lärarboställen," Svensk läraretidning 41 (1922).

22 Thulin (1904-29). Thulin's investigation included the counties of Värmland, Kopparberg, Gävleborg, Västernorrland, Jämtland, Västerbotten and Norrbotten.

23 "Prästgård," http://www.ne.se/lang/prästgård, 4/11 2013; Betänkande angående förändring av extra provinsialläkardistrikt till ordinarie samt ordnande av bostadsfrågan för provinsialläkare å landsbygden ävensom rörande åtgärder för avhjälpande av den inom de norrländska länen rådande läkarbristen m. m (1921), 86; Ulväng (2002), 177-78.

24 Lars Hofstedt et al., Svenska folkskolans historia. Del 5. Det svenska folkundervisningsväsendet 19201942 (Stockholm: 1950), 307-17. 
functions of teachers' allotted farms, and their role in the elementary school system. They have established, among other facts, that public allotted farms played a vital role for the funding of the Swedish army. ${ }^{25}$ However, the significance of teachers' allotted farms for their livelihood and the expansion of the elementary school system in Sweden still require research.

\section{Allotted farms of the Sundsvall region}

In the mid-nineteenth century, the Sundsvall region was largely rural and dominated by smallholders. Although the region experienced an intensive industrialisation process following the expansion of the sawmill industry, it was only in the parishes of Alnö, Njurunda, Skön and Timrå that the industry employed more than half of the working population in $1900 .{ }^{26}$

As the population of the region more than doubled from 18,551 in 1840 to 54,325 in 1900, the school system also expanded. The region's 12 school districts employed 11 teachers in the same number of schools in early 1850 . The number of schools rose to 129 , of which 29 were ambulatory, and there were 161 teachers in $1900 .{ }^{27}$

Under these circumstances 10 out of 12 school districts acquired a total of 13 teacher's allotted farms in the Sundsvall region in 1838-1900 (see Table 1). Eight of these were created using glebe land, which required an application to be sent to the King. These applications seem to have encountered no major difficulties, probably since the region's glebes were usually fairly large, averaging 207 hectares (ha).$^{28}$ Four of the allotted farms were bought, and one was donated by villagers. ${ }^{29}$

The teachers' allotted farms, ranging from 0.5 to 5 ha, averaged 2.3 ha-slightly more than the 1.9 ha that was the average size of the land plots provided by the glebes in the above-mentioned five counties for teachers. ${ }^{30}$ These farms thus seem to have been comparable to the 800 parish clerks' (klockares) allotted farms, mapped in a survey published in 1921. Of these, 41 per cent covered an area below 2 ha, and 20 per cent covered $2-5$ ha. ${ }^{31}$

In size terms, these farms were distinctly smaller than farmers' homesteads, and comparable to the small plots of land cultivated by crofters (torpare). However, this is hardly surprising since, unlike the farmers' homesteads, the teachers' plots were not supposed to be their main source of income. ${ }^{32}$

25 Gerhardsson (1997), 69-70. The function of the military allotment establishment is analysed in Thisner (2014).

26 Lars-Göran Tedebrand, Västernorrland och Nordamerika 1875-1913: Utvandring och återinvandring (Stockholm: Läromedelsförlaget, 1972), 60; Lennart Schön, "Västernorrland in the Middle of the Nineteenth Century: A Study in the Transition from Small-scale to Capitalistic Production," Economy and history 15 (1972), 83-87.

27 Primary data from school boards (1850), H3aaa:9; Statistiska avdelningen, ED, RA; Statistical compilation, Västernorrland county (1900), H3bd:15, Statistiska avdelningen, ED, RA; Folkmängd 1810-1990, Demographic Database (DDB), Umeå University.

28 Gabriel Thulin, Redogörelse för de ecklesiastika boställena: Del 2. Västernorrlands län (Stockholm: s.n., 1906), Table 1.

29 See sources of Table 1.

30 Thulin (1904-29).

31 "Sammandrag över arealen å klockar (organist)-boställen eller- jordar enl. tab. B," in Bihang till riksdagens protokoll (1921) saml. 2 avd. 2 bd 3, Table P.

32 This distinction between crofters and farmers is further discussed in Jonas Lindström, Distribution and Differences: Stratification and the System of Reproduction in a Swedish Peasant Community 1620-1820 (Uppsala: Acta Universitatis Upsaliensis, 2008), 21-22. 


$\begin{array}{llcc}\text { Table 1. Size of teachers' allotted farms } & \text { in } & \text { the Sundsvall region, } & \text { 1838-1900 } \\ \text { School district } & \text { Location } & \text { Year } & \text { Hectares } \\ \text { Hässjö } & \text { Hässjö glebe } & 1853 & 4.9 \\ \text { Indal } & \text { Glömsta glebe } & 1838 & 2.5 \\ \text { Ljustorp } & \text { Mellberg, Rogsta glebe } & 1845 & 2.1 \\ \text { Ljustorp } & \text { Ås village } & 1878 & 0.5 \\ \text { Njurunda } & \text { Njurunda glebe } & 1847 & 0.5 \\ \text { Njurunda } & \text { Baggböle village } & 1864 & \text { n.a. } \\ \text { Njurunda } & \text { Ulvberg village } & 1892 & 2 \\ \text { Selånger } & \text { Nävsta village } & 1847 & 2.6 \\ \text { Skön } & \text { Gran and Stafre glebe } & 1863 & 1.1 \\ \text { Sättna } & \text { Flata glebe } & 1883 & 5 \\ \text { Timrå } & \text { Timrå glebe } & 1859 & 0.9 \\ \text { Tuna } & \text { Ön village } & 1845 & 4 \\ \text { Tynderö } & \text { Tynderö glebe } & 1864 & 1.6 \\ \text { Mean: } & & & 2.3\end{array}$

Sources: Thulin, Redogörelse för de ecklesiastika boställena. 2, Västernorrlands Län, Table 1; Title deeds, Lantmäterimyndigheternas arkiv (LMa, the archives of the Swedish cadastral authorities); Parish meeting, Church meeting and school board minutes, Sundsvall region church archives, Landsarkivet i Härnösand (HLA, Härnösand regional state archives). Cabinet Acts, Ecklesiastikdepartementet (ED), Riksarkivet (RA, the National Archives); Primary data from school boards $(1881,1891)$ and Statistiska avdelningen (Statistical Department), H3aaa: 196, 288, ED, RA. Note: In Alnö and Attmar school districts, teachers were offered housing and outhouses, but no allotted farms. The table includes 13 allotted farms.

The Sundsvall region provides examples of the wide range of allotted farms that the school districts offered. An allotted farm in Njurunda ( 0.5 hectares) was, for example, unable to sustain even a single cow in 1850, while one in Indal (2.5 hectares) was considered adequate for one cow, and one in Skön (1.1 hectares) provided for two cows. ${ }^{33}$ The nature and quality of its soil also varied. For instance, the teacher's allotted farm at Sättna school district, placed in the vicinity of both the schoolhouse and the church, consisted mostly of lowland pasture near the Sättna river (3.5 hectares), but also included 1.4 hectares of arable land (see Figure 1). The allotted farm at Timrå school district included a small herb garden, in addition to fields and meadows, while Tuna school district's allotted farm consisted of 0.85 hectares of fields, 2 hectares of hay meadows and 1 hectare of meadows. ${ }^{34}$

The most extensive descriptions of teachers' allotted farms in the Sundsvall region are of those at Hässjö and Ljustorp. The comparably large allotted farm at Hässjö school district, 4.9 hectares of land parcelled out from a fairly distant part of the glebe, while partly stony, also included relatively extensive areas of arable land. Hilly and forested areas were supplemented by marshes, wet meadows, pasture and fields. Approximately two-thirds of this land (3.2 hectares) was estimated to be arable. ${ }^{35}$

33 School board minutes April 14 1850, K4a:1, Njurunda kyrkoarkiv (ka, church archives), Landsarkivet i Härnösand (HLA); Parish meeting minutes December 11 1842, K1:1, Indal ka, HLA; Parish meeting minutes December 2 1860, K1:4, Skön ka, HLA.

34 Karta öfver förslaget Skollärar-boställe från Sättna prästbol uti Västernorrlands län (1882), O2:1, Sättna ka, HLA; Laga skifte 22-TUN-107 (1847), Lantmäterimyndigheternas arkiv (LMa); Cabinet act December 301859 no. 21 (Timrå), Ecklesiastikdepartementet (ED), Riksarkivet (RA).

35 22-HÄS-115 Arealavmätning (1851), LMa; Cabinet act March 311853 no. 25 (Hässjö), ED, RA. 


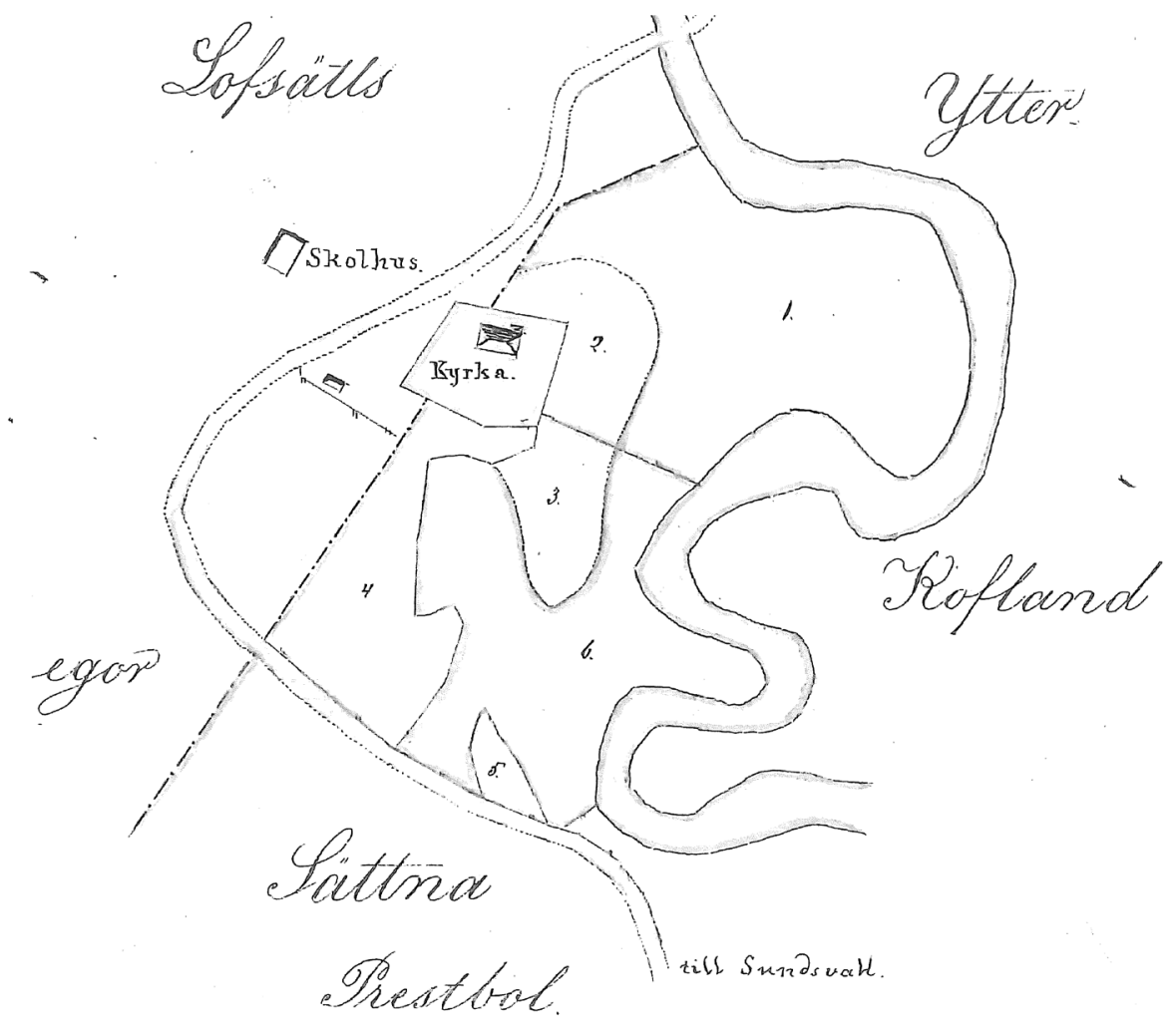

Figure 1. In Sättna, the teacher's allotted farm (numbers 1-6) was placed in the vicinity of the church (kyrka) and the schoolhouse (skolhus). Nos. 1 and 6 are pasture and nos. 2-5 are fields. Map source: Karta öfver föreslaget skollärar-boställe (1882), O2:1, Sättna ka, HLA.

The allotted farm at Mellberg, located in Ljustorp school district, was much smaller and covered only 2.1 hectares of former glebe land. It was located near the parish church, consisting of a yard in the vicinity of the church and a narrowing strip of land. The yard, located on a stony piece of land, was described as very suitable for the purpose. However, the rest of the allotted farm did not receive the same good judgement. While it was indeed largely arable, with the exception of the third that consisted of the narrowest part of the land, it was deemed "sand-like, sterile and particularly frosty". In addition, the land adjacent to the river was partly wooded. ${ }^{36}$

The acquisition of these allotted farms must be understood in the context of contemporary agrarian society. In the mid-nineteenth century, in line with other categories of allotted farms, teachers' allotted farms were an advantageous method of remuneration in a society characterised by a relatively extensive natural economy, where cash might be scarce. Despite increasing contacts with the market, where pro- 
ducts could be purchased and sold, basic foodstuffs were still largely produced and consumed on farms. ${ }^{37}$

The creation of teachers' allotted farms must also be understood in its organisational context. School districts did not invent allotted farms, but rather chose to apply a solution that had worked well in other sectors of society. Such organisational behaviour, termed 'mimetic isomorphism' in organisational theory, has also been identified in analyses of schoolhouse design. ${ }^{38}$ Interestingly, however, school districts started to use allotted farms in an era when they were losing, or on the verge of losing, their significance in the military and civil sector. This time lag is a question that should be addressed in future studies.

When the school districts discussed establishing an allotted farm, they naturally highlighted the possible risks of doing so. For example, could using parts of glebe land to establish an allotted farm result in the remaining forests and the arable land being too small? Was there a risk that the farm, when placed in the vicinity of the church, would damage the beauty, symmetry and piety of the churchyard? Moreover, the creation of a teacher's allotted farm could cause conflicts with the sexton (kyrkvaktmästaren), who also was interested in such benefits. ${ }^{39}$

In general, however, there were several reasons why school districts acquired allotted farms. To begin with, the farms were often relatively inexpensive to acquire. When they were bought, this was done at a comparatively low cost, and when they were parcelled out from the large glebe lands of the Sundsvall region, which was the most common solution, the creation of teachers' allotted farms entailed no sacrifice for either the parish priest or the school district. Even in Hässjö, where the allotted farm (4.9 hectares) was relatively large in comparison with the unusually limited glebe lands ( 28 hectares), the creation of a teacher's allotted farm was understood as fairly unproblematic, since the parcelled land was not deemed to be of any greater benefit to the parish priest. ${ }^{40}$

Allotted farms were also perceived as an important asset, for both the teacher and the school district. They were described as "so necessary and valuable to officials residing in rural areas", and also judged to be a good investment that made schooling more affordable for the school district. ${ }^{41}$ In Timrå, the school district compared its allotted farms to a fund: creating an allotted farm was equivalent to investing in a fund of 2,500 Swedish kronor (SEK), which at the interest rate of 5 per cent gave the annual return of 125 SEK. ${ }^{42}$ In Indal, the teacher's allotted farm (2.5 ha) was described as an insurance against additional expense in the school system, and in Sättna

37 Gerhardsson (1997), 69; Carl-Johan Gadd, "The Agricultural Revolution in Sweden 1700-1870," in The Agrarian History of Sweden: 4000 BC to AD 2000, ed. Janken Myrdal and Mats Morell (Lund: Nordic Academic Press, 2011), 130-32. Regarding the natural economy of the Sundsvall region, see Lars-Göran Tedebrand, Selånger: En sockens historia (Sundsvall: Selångers församling, 1983), $112-14,145-46$.

38 Johannes Westberg, Att bygga ett skolväsende: Folkskolans förutsättningar och framväxt 1840-1900 (Lund: Nordic Academic Press, 2014), 129.

39 See e.g., Parish meeting minutes December 2 1849, May 20 1850, K1:3, Timrå ka, HLA; Cabinet act March 311853 no. 25 (Hässjö), ED, RA.

40 Cabinet act March 311853 no. 25 (Hässjö), ED, RA

41 Cabinet act October 191883 no. 14 (Sättna), ED. RA. The quote is from Cabinet act May 121857 no. 17 (Tuna), ED, RA.

42 Cabinet act September 211894 no.21 (Njurunda), ED, RA. 
the parishioners simply declared that acquiring a farm was better than having to pay the teacher a higher salary. ${ }^{43}$

In certain cases, the allotted farms' return was perceived as particularly important. For instance, the parishioners of Skön noticed that the inhabitants of the school district were heavily taxed, and that the district was especially poor in terms of hay: each pound of hay was very valuable in their minds. The establishment of a teacher's allotted farm, which could easily feed two cows, was therefore desirable, since it meant that the parishioners did not have to provide the teacher with an amount of hay that was vividly described as "severe, cumbersome and at times also unpleasant". ${ }^{44}$

\section{Cowsheds, bakehouses and cellars}

The allotted farms included a number of outhouses, which gave them the character of small farmsteads. Although these buildings are not explicitly mentioned in the Swedish Elementary School Acts of the nineteenth century, and has been given scant consideration in the previous literature, their presence was assumed in the contemporary education debates and in the implementation of the Elementary School Acts of 1842 and $1882 .{ }^{45}$ For instance, Anders Oldberg, a well-known educationalist, argued that the operation of a school district required a number of outhouses, among which he mentioned a woodshed, a laundry and mangle shed, a cowshed and a barn. This is confirmed by the National Building plans for schoolhouses (1865 and 1878 editions), which list cowsheds, cellars, barns, woodsheds and pigsties. ${ }^{46}$

As with the acquisition of the allotted farms, the construction of these outhouses was motivated by the still extensive natural economy in the rural parishes of the Sundsvall region. In the school districts of this region, the outhouses were largely a matter of satisfying the teacher's needs in an agrarian setting. According to the parishioners, their teacher needed a cowshed, without which rural life would be both costly and cumbersome, and a cellar was described as a necessity for the school teacher's household, both in the present and in the future. ${ }^{47}$

The construction of outhouses was also motivated with reference to the Elementary School Act of 1842. As mentioned above, the salary terms of the Act encouraged school districts to supply teachers with a plot of land, and in the eyes of the school districts this also had further consequences. The school board of Tynderö, reading between the lines of the above-mentioned Act, claimed that it required school districts to provide the teacher with the necessary buildings. Since the teacher

43 Church meeting minutes March 9 1873, K1:5, Sättna ka, HLA; Parish meeting minutes May 12 1844, K1:4, Indal ka, HLA.

44 Parish meeting minutes December 29 1861, K1:4, Skön ka, HLA.

45 SFS 1842:19; SFS SFS 1882:8. See e.g., Hjördis Kristenson, Skolhuset: Idé och form (Lund: Signum, 2005); Anders Åman, "Inledning till skol-arkitekturen: Om Uppsala läroverk och svenskt skolhusbyggande i de stora undervisningsreformernas spår," Upplands nations årsskrift 25, (1962).

46 Anders Oldberg, Praktisk handbok i Pedagogik och methodik för Swenska folkunderwisningen (Stockholm: L. J. Hierta, 1846), 151; Öfverintendentsembetet, Normalritningar till folkskolebyggnader jemte beskrifning (Stockholm: s.n., 1865), 25-26; Öfverintendentsembetet, Normalritningar till folkskolebyggnader jemte beskrifning: Andra omarbetade upplagan. (Stockholm: s.n., 1878), 15-16. See also Adam Crispin Peterson, "Folkskolebyggnader," Tidskrift för byggnadskonst och ingeniörvetenskap 6, (1864), 182 and Fig. 6.

47 Parish meeting minutes January 26 1855, K1:5, Attmar ka, HLA; School board minutes February 7 1858, K2:1, Tuna ka, HLA. See also Parish meeting minutes April 9 1855, K1:3, Sättna ka, HLA; Parish meeting minutes February 8 1846, K1:3, Njurunda ka, HLA. 
needed a cellar, the school district consequently had to build a cellar at the schoolhouse. ${ }^{48}$ Similarly, the parishioners of Ljustorp declared that it was necessary, "in accordance with the rules of the School Act", to build a cowshed. ${ }^{49}$

\section{The school districts' stock of outhouses}

According to the state school inspector, the teachers of Härnösand's diocese, which included the whole of northern Sweden, were usually provided with a number of outhouses, alongside apartments consisting of a kitchen and two or three additional rooms. However, the number, purpose and condition of buildings varied greatly, which the inspector believed was due to the lack of precision in the School Act. ${ }^{50}$

The available source materials are insufficient for a complete inventory of all the outhouses of the teachers' allotted farms in 1838-1900. The minutes and accounts of the school districts do not cover all the outhouses built, and when erection or repair of an outhouse is mentioned it is not always possible to identify the outhouse referred to. Still, the evidence that has been found in the available source materials does allow a brief survey of the outhouses maintained by the Sundsvall region's school districts.

Table 2. Outhouses of teachers' allotted farms in Sundsvall region, 1838-1900

\section{Outhouse}

Brewhouse

Cowshed

Woodshed

Bakehouse

Cellar

Barn

Stables

Granary

Storehouse

Threshing barn

Drying house

Sources: Fire insurance, General Fire Insurance Board; Cabinet Acts, ED, RA; School district account books, Parish meeting, Church meeting and school board minutes, the church archives of Sundsvall region, HLA. Note that this table also includes the school districts of Alnö and Attmar, which, despite not owning public allotted farms, provided the teachers with outhouses such as cowsheds, barns and woodsheds. The table includes 12 kinds of outhouses and 78 evidences.

As shown in Table 2, the building stock of Sundsvall region's school district included more than just a schoolhouse: there is evidence that the teacher received several outhouses, usually including a brewhouse, a cowshed, a woodshed, a bakehouse, a cellar and a barn. An example of such a set of outhouses is seen at the Kyrkmon's school in Njurunda, which in 1894 included a brewhouse, a barn, a woodshed, a th-

48 Parish meeting minutes September 12 1858, K1:1, Tynderö ka, HLA.

49 Parish meeting minutes September 12 1847, K1:3, Ljustorp ka, HLA. See also Parish meeting minutes April 15 1860, K1:3, Timrå ka, HLA.

50 S. H. Wagenius, "Berättelse om Folkskolorna inom Hernösands stift åren 1864-1866: Ångermanlands södra och östra kontrakt samt Medelpad," in Berättelse om folkskolorna i riket för åren 18641866 (Stockholm: Nordstedt \& söner, 1867), 14. 
reshing barn and a stone cellar. Another example is the teacher's allotted farm at Ön in Tuna, to which at least a cowshed, a bakehouse, a cellar and a stable belonged. ${ }^{51}$

The teachers' allotted farms' stock of outhouses appears in line with other similar residences of the period under study. With the exception of pigsties, teachers' allotted farms had the usual features of a medium-sized farm in the Sundsvall region in the first half of the nineteenth century. ${ }^{52}$ In comparison, the parish clerk's allotted farms might include a residential building, sheds, a barn, a cattle shed and stables, depending on local traditions and requirement. ${ }^{53}$ Soldiers' allotted farms might include a cowshed, a threshing barn, sheds and a fodder barn, and the lighthouse keepers' cottages were usually accompanied by a woodshed, wash and bakehouse, a cellar and kerosene huts. ${ }^{54}$

As shown in Table 2, not all teachers' allotted farms included the same set of outhouses: many lacked stables, granaries and drying houses, which were intended for the drying of grains. In addition, only two allotted farms included threshing barns, intended for grain processing.

While the causes of such variations will not be investigated further in this article, some observations may nonetheless be made. It may, for example, be noted that, in some cases, the decision not to build an outhouse was based on the fact that the outhouses already present at the allotted farms was considered sufficient for the teacher's needs, or that the teacher was allowed to use outhouses in the vicinity of his allotted farm. It was, for example, noted in Timrå that a hay barn did not have to be erected on the teacher's allotted farm, since the hay could be transported to the fodder barn at the schoolhouse. ${ }^{55}$ There were also instances when teachers were given the opportunity to dry grain and bake bread in neighbouring farms, and allowed to keep their grain in the parish granary (sockenmagasin). ${ }^{56}$ In such instances, drying houses, bakehouses and fodder barns would not have been necessary.

\section{The nature of the outhouses}

In general, the teachers' outhouses were not particularly large, and tended to adapt to the small size of the allotted farms. Table 3 shows how a teacher's cowshed could cover just over 15 square metres, a cellar 13 sq.m. and a row of outhouses, consisting of a cowshed and more, 60 sq.m. In comparison with, for example, farmers' outhouses in the county of Uppland, these were comparatively small. For the latter, figures related to 1860 indicate that cattle sheds occupied 80 sq.m. and barns 120 sq.m., which greatly exceeded the hay barns of the school districts studied. ${ }^{57}$

51 School board minutes May 14 1894, K3a:1, Njurunda ka, HLA; Parish meeting minutes February 21 1858, K1:7, Tuna ka, HLA; Parish meeting minutes November 12 1871, K1:8, September 9 1872, Tuna ka, HLA.

52 Tedebrand (1983), 107. Regarding farmsteads in the county of Uppland, see Göran Ulväng, Hus och gård i förändring: Uppländska herrgårdar, boställen och bondgårdar under 1700- och 1800-talens agrara revolution (Hedemora: Gidlund, 2004), Chapter 7.

53 Gabriel Thulin, Utredning angående klockar-, organist- och kantors (kyrkosångar) befattningarna. Avdelning 1. (Stockholm: s.n., 1919), 177.

54 Elfred Kumm, Indelt soldat och rotebonde (Stockholm: LT, 1989), 169; Thunman (2000), 130-46.

55 Parish meeting minutes September 2 1860, K1:3, Timrå ka, HLA.

56 E.g. Parish meeting minutes February 11 1849, K1:5, Ljustorp ka, HLA; Parish meeting minutes December 30 1849, K1:1, Alnö ka, HLA.

57 The outhouses of farmsteads in Uppland are described in Ulväng (2004), 198. 
The outhouses were also, in general, not particularly costly. Judging from the school districts' minutes and accounts, cowsheds cost 210-350 SEK to build, while a stable might cost 103 SEK and a barley barn 226 SEK (see Table 4). ${ }^{58}$ At these prices, a set of buildings consisting of a cowshed, a hay barn, a woodshed, a stable, a privy and a cellar could be built for 619 SEK, while a less costly set of cowshed, woodshed, threshing barn, brewhouse, cellar and hay barn might be constructed for a little over half the price (349 SEK). In comparison with the investment required for a schoolhouse, these costs were minor. The cost of a schoolhouse in the Sundsvall region averaged 2,400 SEK in the 1840 s and 8,600 SEK in the 1870 s. $^{59}$

$\begin{array}{lllll}\text { Table 3. Dimensions of teachers' } & \text { outhouses in } & \text { the Sundsvall region } \\ \text { Outhouse } & \text { Year built } & \text { Width, m } & \text { Length, m } & \text { Area, m2 } \\ \text { Barley barn } & 1872 & 5.9 & 5.9 & 34.8 \\ \text { Brewhouse } & 1883 & 5.0 & 7.1 & 35.5 \\ \text { Cellar } & 1886 & 3.6 & 3.6 & 13.0 \\ \text { Cowshed } & 1847 & 3.6 & 4.2 & 15.1 \\ \text { Hay barn } & 1896 & 6.5 & 6.5 & 42.3 \\ \text { Row of outhouses } & 1896 & 4.8 & 12.5 & 60.0\end{array}$

Sources: Fire insurance, General Fire Insurance Board; Parish meeting, Church meeting and school board minutes, church archives of the Sundsvall region, HLA.

$\begin{array}{lclc}\text { Table 4. The cost of building teachers'farm outhouses in the Sundsvall region } \\ \text { School district } & \text { Year built } & \text { Building } & \text { SEK } \\ \text { Tuna } & 1847 & \text { Stable } & 103 \\ \text { Njurunda } & 1852 & \text { Hay barn } & 19 \\ \text { Tuna } & 1858 & \text { Cellar } & 200 \\ \text { Indal } & 1883 & \text { Cowshed } & 250 \\ \text { Njurunda } & 1884 & \text { Barley barn } & 226 \\ \text { Sättna } & 1884 & \text { Cowshed } & 210 \\ \text { Attmar } & 1887 & \text { Cowshed } & 350 \\ \text { Hässjö } & 1891 & \text { Woodshed, stable and privy } & 150 \\ \text { Ljustorp } & 1892 & \text { Cowshed } & 220 \\ \text { Njurunda } & 1896 & \text { Cowshed, woodshed, threshing } & 130\end{array}$

Sources: School district account books, Parish meeting, Church meeting and school board minutes, and Sundsvall region church archives, HLA.

The above-mentioned outhouses were built with varying purposes and followed different designs. The cowsheds, which belonged to the allotted farms' standard building stock, were, like other outhouses, often included in a row of stables and sheds, which was a common building design in Sweden in the nineteenth century. ${ }^{60}$ For example, Sättna school district built a row of outhouses consisting of a cowshed, a

58 Note that the currencies preceding Swedish kronor (SEK) have been converted to SEK following the exchange rates presented in Klas Fregert and Roger Gustafsson, "Fiscal Statistics for Sweden 1719-2003," Research in Economic History 25, no. 1 (2008), 176-77. Since an adjustment of the nominal prices to consumer price index does not affect the study's result appreciably, nominal values are presented in this article.

59 Johannes Westberg, "How Much did a Swedish Schoolhouse Cost to build? Rewriting the History of Nineteenth Century Rural Schoolhouses," Scandinavian Journal of History 39, no. 4 (2014), 455.

60 Ulväng (2004), 198-99. 
fodder barn, a privy and a woodshed, and similar solutions were implemented in Skön and Tuna. ${ }^{61}$

While cowsheds were typically built using timber, some school districts used slag bricks (slaggtegel). ${ }^{62}$ Like those built by the region's farmers, they might also be furnished with a fireplace, for heating cattle feed during the winter. ${ }^{63}$ The size of the cowsheds varied but, as previously noted, judging from extant source materials, they accommodated one or two cows that teachers typically kept. ${ }^{64}$

The cowsheds had a fairly short life span, which must be acknowledged in order to appreciate the work needed for their maintenance. A study of cowsheds in the county of Uppland suggests that these, on average, had an expected life span of about thirty years, and the conditions of Sundsvall region also took their toll upon cowsheds erected within the school district. ${ }^{65}$ In Ljustorp, the first cowshed was built in 1847 and only 14 years later, in 1861, it was noted that it had become old and so inadequate that cattle could be kept there during the winter only with great difficulty. ${ }^{66}$ A similar development can be seen in Indal, where a cowshed was built in 1844 . Fourteen years later, in 1858 , a decision was made to collect timber for a new cowshed, which seems to have lasted longer. In 1878, the roof and chimney failed a fire inspection, prompting extensive repairs, and in 1883, a new cowshed was constructed. ${ }^{67}$

Aside from cowsheds, brew and bakehouses were, as shown in Table 2, commonplace. These were also wooden buildings, and usually had the form of a traditional so-called enkelstuga - a house consisting of three rooms: a larger room where the baking oven was placed, a chamber and an entrance. ${ }^{68}$ The bakehouses were intended for the baking of bread, and the brewhouses were traditionally used for brewing beer, distilling spirits and washing clothes. In such cases, laundry was boiled in vessels in the largest room of the house, and thereafter dried in the attic. ${ }^{69}$ In addition, the brewhouses were often used as kitchens in the summer, and also provided the households with extra living space at this time of year. ${ }^{70}$

In comparison with the cowsheds, the brew and bakehouses seems to have been somewhat more durable. For example, in the school district of Timra and Indal, the first brewhouse was built in 1845, while the corresponding dates were 1846 in Nju-

61 Parish meeting minutes April 9 1855, K1:3, Sättna ka, HLA; Church meeting minutes August 18 1878, K2:2, Skön ka, HLA; School board minutes August 23 1880, K2:2, Tuna ka, HLA.

62 See e.g., Church meeting minutes July 24 1887, K1:7, Attmar ka, HLA.

63 School board minutes August 4 1878, K4a:2, Indal ka, HLA; Karta med beskrivning (Ljustorps socken), 1858, X33-1:3, Lantmäteristyrelsens arkiv (LMS).

64 School board minutes November 2 1884, K2:2, Tuna ka, HLA. See also Parish meeting minutes January 26 1855, K1:5, Attmar ka, HLA; Parish meeting minutes March 13 1894, K1:5, Indal ka, HLA.

65 Ulväng (2004), 198-99.

66 Parish meeting minutes September 12 1847, K1:3, Ljustorp ka, HLA; School board minutes December 22 1861, K4a:2, Ljustorp ka, HLA.

67 Parish meeting minutes May 12 1844, December 19 1858, K1:4, Indal ka, HLA; School board minutes August 4 1878, June 21 1883, K4a:2, Indal ka, HLA.

68 Ulväng (2004), 206.

69 Ulväng (2004), 109.

70 Ulväng (2004), 204-5. 


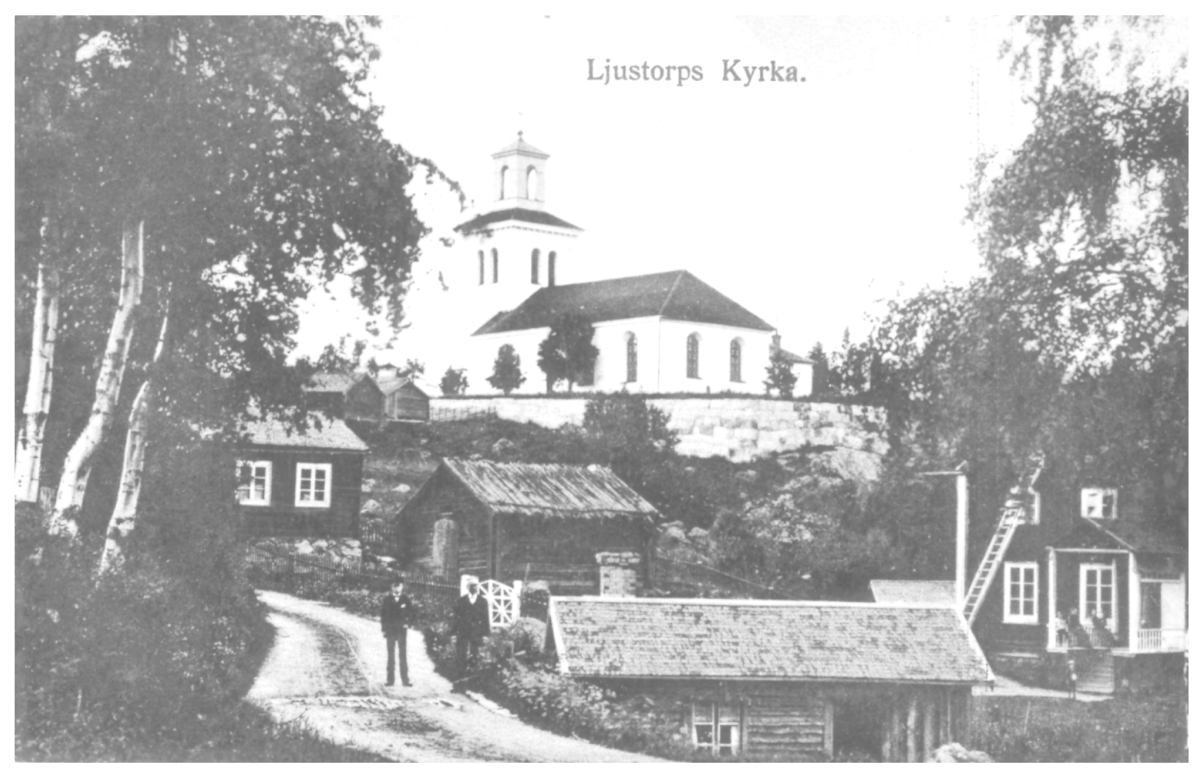

Figure 2. The teacher's allotted farm in Mellberg, Ljustorp, included a bakehouse, a cowshed, a cellar, a barley barn and a woodshed. The picture shows the bakehouse on the far left, where there also was room for the teacher to make handicrafts. The woodshed was positioned just below the bakehouse, and at the bottom of the image, the bakehouse of the glebe is visible. The short side of the schoolhouse is to the right. ${ }^{71}$ Source: Ljustorps hembygdsförening (Ljustorp local history and cultural heritage association), Fo-10334.

runda, 1850 in Alnö and 1854 in Tynderö. ${ }^{72}$ The weak point of these buildings was the fireplace. In Indal, the baking oven was rebuilt in 1866 and again in 1897. In Skön a new brewhouse was built in 1875, when the old one had become unusable, and in 1893 it was rebuilt following a fire. The bakehouse in Tuna burnt down in $1871 .^{73}$

The common practice of using brewhouses, as shown in Table 2, is noteworthy. Regarding farmsteads in Uppland, brewhouses have been described as a part of their raised standards in the nineteenth century, although they were still fairly uncommon among farmsteads in Uppland. ${ }^{74}$ Still, the reasons why brewhouses were erected at teachers' allotted farms in the Sundsvall region so frequently are worth exploring. One reason was certainly that the brew and bakehouses had overlapping designations, which meant that the latter might have been described as the former in the source materials. In certain cases, a building might also be designated as a "brew- and bakehouse". 75 The popularity of brewhouses may also be explained by the fact that they could be used to fulfil a number of functions. As mentioned above,

71 Sven Hedin, Ljustorp förr och nu: Bygd och människor. Del 1: Seder och bruk (Ljustorp: Sveriges pensionärsförbund, 1990), 145.

72 See the sources of Table 2.

73 Church meeting minutes September 12 1875, September 10 1893, K2:2, Skön ka, HLA; School board minutes April 16 1866, K4a:1, Indal ka, HLA; School board minutes May 16 1897, K4a:2, Indal ka, HLA; Church meeting minutes, November 12 1871, K1:8, Tuna ka, HLA.

74 Ulväng (2004), 204-5.

75 E.g., Parish meeting minutes October 16 1859, K1:5, Attmar ka, HLA; Parish meeting minutes November 27 1859, K1:3, Timrå ka, HLA. 
they had traditionally been used for brewing, distilling and washing, and the school districts also used them as apartments. ${ }^{76}$

Outhouses designed for different storage purposes were also a fundamental part of the allotted farms' building stock. As shown above, woodsheds, where the firewood intended for the school and the teacher's apartment was stored, granaries, intended for instance for cattle feed or threshed grain, and hay barns, were in evidence. ${ }^{77}$ In addition, in the absence of latter-day methods for preserving food, the root cellars were of great importance and could thus be found throughout Sweden. ${ }^{78}$ As food preservation benefited from a steady humidity and low temperature, the allotted farms' cellars were usually made of stone and dug into the ground or a hillside, or placed under the schoolhouse. ${ }^{79}$

\section{Teachers' work on allotted farms}

Alongside the land and outhouses, the teachers' allotted farms required a certain amount of labour from the teacher and his household. As shown, primarily by nonSwedish research, it was not uncommon for teachers in the eighteenth and nineteenth centuries to engage in a wide range of occupations. ${ }^{80}$ This may differ from the working conditions of latter-day teachers, but it is not that surprising. A striking feature of the rural labour force was livelihood diversification, which meant that individuals earned their living through a multitude of more or less temporary employments. ${ }^{81}$

Among the societal preconditions that made the teachers' allotted farms possible was the fact that Sweden was a largely rural country in the mid-nineteenth century. Although the industrialisation process was especially marked in the Sundsvall region, it is probable that the skills necessary to run an allotted farm were well distributed among teachers even at the turn of the century. These allotted farms also benefited from teachers' limited teaching obligations, which were particularly restricted in the years following the Elementary School Act of 1842. For children who attended Sweden's elementary schools in 1843, the estimated school year consisted of only 60 days, spread over 29 weeks. In the Sundsvall region, there might be as few as 16-19 school weeks, occasionally divided into three terms: spring (mid-February to end of March), summer (one month between sowing and harvesting) and autumn (1 October-25 November).$^{82}$ This, of course, left the teacher with enough time to devote to other matters.

76 See e.g., Parish meeting minutes June 9 1862, K1:4, Timrå ka, HLA; School board minutes December 2 1888, K2:3, Tuna ka, HLA; School board minutes, October 22 1882, January 30 1884, K2:2, Tuna ka, HLA.

77 See the sources of Table 2.

78 See e.g., Catharina Svala, Från ladu-gård till djur-stall: Ekonomibyggnader under 250 år (Lund: Kungl. Skogs- och Lantbruksakademien, 1993), 91.

79 E.g., Parish meeting minutes, June 22 1862, May 19 1878, K1:4, Timrå Ka, HLA: Parish meeting minutes February 21 1858, K1:7, Tuna ka, HLA.

80 See e.g., Day (1983); Brühwiler (2012b).

81 See e.g., the articles included in Benny Jacobsson and Maria Ågren, eds., Levebröd: Vad vet vi om tidigmodern könsarbetsdelning? (Uppsala: Swedish Science Press, 2011).

82 Jonas Ljungberg and Anders Nilsson, "Human capital and economic growth: Sweden 1870-2000," Cliometrica 3, no. 1 (2009), tab. 1; Statistical compilation, Härnösand's diocese (1865), H3abd:1, Statistiska avdelningen, ED, RA. See also School Regulations (1850), G3b:5, Domkapitlet i Härnösands stift, HLA. 
The work carried out by the teacher and his household, which at times also could include farmhands and maids, was varied. Alongside animal husbandry, spring cultivation and harvesting, the preparation and storage of grain, teachers maintained and often built the allotted farm's outhouses. In addition, teachers and their households would cultivate potato patches and herb gardens, and some were entitled to pursue a certain amount of fishing and tree-felling in the allotted farm's forest. ${ }^{83}$

Extant minutes and other written documents provide a more detailed insight into the labour performed by the teacher's household. Judging from these, it is evident why teachers' allotted farms were a resource for the school districts, making the establishment of schools affordable. In addition to providing the school districts with a portion of the teachers' salaries, the labour that the teacher and his household invested in the property kept down the school districts' expenditure on items like sowing, harvesting and the building and maintenance of outhouses. Such items of expenditure were instead incurred largely by teachers, who were not always remunerated for their efforts at the allotted farms.

Teachers usually assumed major responsibility for the construction and repair of outhouses, and there are plenty of examples of teachers building sheds, stables, privies, fodder barns and cellars. ${ }^{84}$ The expenditure associated with this work would, fully or partially, be incurred by the teacher. In Selånger, for instance, the teacher was responsible for all repairs of fences, barns and other outhouses, and in Indal the teacher himself built the brewhouse without any compensation in 1845. In addition to a cellar, the teacher Wästin in Tuna school district built two large barns and a carriage shed, and constructed three pantries in the schoolhouse. He had also plastered the cowshed and the stables, and put up 700 metres of wooden fencing. The school district, however, only covered less than half the expenses associated with this work..$^{85}$

The fields and meadows also required a certain amount of labour that, in contrast to the work done on outhouses, was always unpaid. What first comes to mind, of course, is the harvesting. Hay, for example, had to be cut, turned, raked and piled on hay fences (hässjor) to dry, before being transported to barns for storage. According to a contemporary manual from the Sundsvall region, written in the 1860s, the haymaking would begin in the morning between four and five oclock, and continue throughout the day, interrupted only by meals served by the household's women. ${ }^{86}$

Available statistical data may provide us with a rough estimate of the amount of hay harvested. If, for example, the allotted farms provided a yield equivalent to the average value of cattle feed presented to teachers in the region, this meant that the

83 Cabinet act September 91894 no. 21 (Njurunda), ED, RA; Parish meeting minutes June 191859 , K1:3, Timrå ka, HLA; School board minutes February 3 1878, K2:2, Tuna ka, HLA; 22-NJU-5879 Avsöndring (1892), LMa. Regarding grazing in forests, see also 22-LJU-1488 Avsöndring (1878), LMa.

84 See e.g., Parish meeting minutes October 27 1878, K1:7, Attmar ka, HLA. See also School board minutes October 9 1891, K3a:2, Hässjö ka, HLA; Church meeting minutes February 7 1858, K2:1, Tuna ka, HLA.

85 School board minutes June 22 1857, K1:5, Selånger ka, HLA; Letter to the Church meeting October 18 1884, K2:1, Tuna ka, HLA.

86 Christina Wiklund, Moster Wiklunds handbok (Sundsvall: Nils Wide, 2007), "Slått och Hö bärgning m.m." 
teachers and his household harvested 1.2 tonnes of hay at each allotted farm. ${ }^{87}$ Available figures also suggest that the size of the harvests varied among the allotted farms. The allotted farm of Ås (Ljustorp), for instance, yielded 1.7 tonnes of hay and $350 \mathrm{~kg}$ of barley straw, while the allotted farm of Tuna (4 hectares) yielded a sum equal to 6 tonnes of hay. ${ }^{88}$

Harvesting also required the labour of ploughing, sowing and fertilising. What this implied is not easily determined, since school districts' descriptions of the teachers work were usually fairly general, concluding, for example, that the teacher had expanded and improved the fields at the Baggböle allotted farm. ${ }^{89}$ However, when the school district on occasion let the allotted farms to tenants who were not teachers, more detailed contracts were drawn up.

In 1857, before school teacher Isak Söderberg was able to rent the teacher's allotted farm in Selånger, it was let to the highest bidder. According to the contract, the tenant was to leave half the older fields fallow, and to plough and sow the remaining fields with at least three barrels of grain. The tenant was also to expand the allotted farm's field by ploughing and ditching half a hectare of land. In total, the allotted farms' fields were to be fertilised with 80 loads of manure, which probably corresponded to about 27 tonnes..$^{90}$ Other contracts also included maintenance of fences and roofs, protecting the crops from grazing cattle, and ploughing and fertilising the fields. ${ }^{91}$

Besides this agricultural work, needed if the allotted farms were to be able to provide the teacher with part of his salary, there were also tasks to be performed in the allotted farm's forests. These were sometimes significant for both the return on and the maintenance of the allotted farm. Cows were herded in the woods, which was also where teachers cut timber and made use of the bogs (myren). The tenant at the teacher's allotted farm of Ulvsberg, bought by Njurunda school district in 1892, was entitled to cut the requisite timber for fences and hay fences, for example. He was also permitted to let his cattle graze in the woods, and to extract 15 loads (5.1 tonnes) of fertiliser from the forests' bogs. ${ }^{92}$

Firewood was another issue. The School Act of 1842 entitled the teacher to "necessary fuel", and in this regard teacher's allotted farms could serve as a simple solution when a steady supply of firewood was required..$^{93}$ In such instances, the school district needed neither to buy firewood nor to tax the school district's inhabitants in kind, but only to tell the teacher where he should cut and collect his firewood. ${ }^{94}$

87 Primary data from school boards $(1860,1885,1891)$, H3aaa: 30, 232, 288, Statistiska avdelningen, ED, RA; The price data used in these calculations are available in Lennart Jörberg, A History of Prices in Sweden 1732-1914. Volume 1: Sources, Methods, Tables (Lund: Gleerup, 1972).

88 School district account book 1886, L2a:1, Ljustorp ka, HLA; Primary data from school boards (1891), H3aaa: 288, Statistiska avdelningen, ED, RA.

89 School board minutes May 14 1894, K3a:1, Njurunda ka, HLA.

90 A load (lass) of manure is assumed to correspond to a load of hay in Västernorrland, that is 340 kilogram. Jörberg (1972), 87.

91 See e.g., School board minutes June 2 1884, K2:2, Tuna ka, HLA.

92 22-NJU-5879 Avsöndring (1892), LMa.

93 SFS 1842:19, $\$ 4$.

94 See e.g., School board minutes June 22 1857, K1:5, Selånger ka, HLA; Parish meeting minutes September 12 1858, K1:7, Tuna ka, HLA; Church meeting minutes January 16 1859, K2:1, Tuna ka, HLA. 
The extent of work carried out at the teachers' allotted farms is, obviously, difficult to estimate, since it depended on a large number of factors. Using available time estimates for performing a certain amount of agricultural work, it may be noted that the grain and hay harvests at Tuna and Hässjö allotted farms would require totals of 22 and 33 days' labour (dagsverken) respectively, i.e. 4-5 six-day working weeks for one individual..$^{95}$ Including such tasks as ploughing and sowing, and the work needed to maintain the allotted farm's outhouses, makes it clear that maintaining the allotted farms was relatively time-consuming for the teacher and his household, not least in comparison with the relatively light teaching burdens. If the teacher was responsible for building an outhouse, the workload became even greater. Building the new cowshed in Sättna in 1884, for example, probably required around 45 days' labour, i.e. 2-3 weeks' labour if the teacher had hired two day labourers. ${ }^{96}$

\section{The changing significance of teachers' allotted farms}

As shown above, teachers' allotted farms played various roles following the School Act of 1842, and were perceived as an asset that benefited both the teacher and the school district. Measuring the economic impact of teachers' allotted farms on school districts is, however, difficult, primarily because the school districts rarely recorded harvest size or value.

Available statistical data and individual examples can, however, be utilised to make an initial rough estimate of the economic importance of these allotted farms, as well as its trend over time. It is evident that allotted farms could cover a significant proportion of individual teacher's salaries. The return from the allotted farm in Ås (Ljustorp) corresponded, for example, to 26 per cent of the teacher's salary in 1886, and in 1891, the allotted farm in Tuna supplied its teacher with 22 per cent of his income. ${ }^{97}$ When poor harvests hit Njurunda in 1874, the school district compensated the teacher's reduced harvest with a sum amounting to 23 per cent of his salary. ${ }^{98}$ However, the yield might also be less significant. In 1860, the return on the allotted farm of Ljustorp was estimated as the equivalent of 50 SEK, representing only 11 per cent of the teacher's salary. ${ }^{99}$

Unfortunately, such examples cannot be used in order to establish the allotted farms' contribution to the school districts' total revenues, which mainly consisted of central government grants and local taxation. ${ }^{100}$ In the absence of sufficient data on the allotted farms' returns, a comparison between the cost of cattle feed, which

95 Each day's labour is assumed to be 10 hours' work. Janken Myrdal, "Betingsläror och arbetsåtgång i lantbruket," in Landbon, ladan och lagen och hägnaderna, arbetstiden och bygdelaget samt ytterligare 20 agrarhistoriska artiklar, ed. Anders Perlinge (Stockholm: Kungl. Skogs- och lantbruksakademien, 1996), 151-58.

96 The number of days' labour has been estimated using the cost estimate for a new cowshed, presented in Church meeting minutes June 22 1884, K1:5, Sättna ka, HLA.

97 School district account books 1886, L2a:1, Ljustorp ka, HLA; Primary data from school boards (1885, 1891), H3aaa: 232, 288, Statistiska avdelningen, ED, RA. Similar estimates were made by Tuna school district in 1884, see Letter to the Church meeting October 18 1884, K2:1, Tuna ka, HLA.

98 School board minutes September 20 1874, K4a:1, Njurunda ka, HLA; Primary data from school boards (1874), H3aaa: 91, Statistiska avdelningen, ED, RA.

99 Primary data from school boards (1860), H3aaa: 30, Statistiska avdelningen, ED, RA.

100 Westberg (2013), 1-22. 
the allotted farms were supposed to cover as a minimum, and the school districts' total expenditure on salaries, may serve as an appropriate starting point. Based on such data, the returns of the allotted farms in 1865, when ten school districts with 17 teachers owned eight allotted farms, corresponded to 15 per cent of the salaries in these school districts, and 11 per cent of the salary bill in all twelve school districts. ${ }^{101}$

Based on such rough estimates, it is likely that the significance of the teachers' allotted farms for the funding of the Swedish elementary school declined in the second half of the nineteenth century. This development should, obviously, be related to the general changes that took place in the Swedish society in the nineteenth century, where production growth due to the agrarian and industrial revolutions contributed to an expanding monetary economy that diminished the role of all ecclesiastical, military, and civil allotted farms. ${ }^{102}$

There were also, however, more specific factors underlying the decline in importance of teachers' allotted farms. In addition to increasing teaching duties and a prolonged school year, which meant that teachers had less time to devote to activities outside school, the main reason was the substantial increase in the school districts' operations. In 1900, the number of teachers in the Sundsvall region had multiplied from 17 in 1865 to 161 in 1900, which also meant an increase in the total payroll from 8,000 SEK to 130,500 SEK. If the 13 allotted farms at this time contributed to the school districts' revenues at the level equivalent to the cost of cattle feed in 1865, this would mean that they accounted for less than 1 per cent of the total wage bill in $1900 .{ }^{103}$ The allotted farms of Ljustorp and Tuna, where the return of the allotted farms can be accounted for, are good examples of this development. In these school districts, the allotted farms still accounted for between a fifth and a quarter of individual teacher's wages in the 1880 s and 1890s, as noted above, but in terms of total salary costs they contributed only 3-6 per cent. ${ }^{104}$

The limitations of such rough estimates notwithstanding, it seems reasonable to argue that the economic impact of the teachers' allotted farms declined over time. From having been of significant importance for both individual teachers and school districts, the allotted farms became a rather marginal phenomenon.

\section{Conclusions}

The school districts' allotted farms were small, comparable to the farmsteads of crofters and parish clerks, consisting on average of 2.3 hectares of land, including forests, bogs and marshes, fields and meadows. On this land, farm outhouses, such as brewhouses, cowsheds, woodsheds, bakehouses, cellars and barns were located. It was on this site that teachers and their households performed a wide variety of agricultural work, including animal husbandry, harvesting and building maintenance.

In relation to previous studies on the history of mass schooling, this article sheds

101 Primary data from school boards (1865), H3aaa: 47, Statistiska avdelningen, ED, RA.

102 The agrarian and the industrial revolutions in Sweden are described in Lars Magnusson, An Economic History of Sweden (London: Routledge, 2000), Chapters 1 and 6.

103 Primary data from school boards (1865), H3aaa: 47, Statistiska avdelningen, ED, RA; Statistical compilation, Västernorrland county (1900), H3bd:15, Statistiska avdelningen, ED, RA. For a rough estimate of teacher's salaries' trends in Sweden, see Olle Krantz, Historiska nationalräkenskaper för Sverige: Offentlig verksamhet 1800-1980 (Lund: Studentlitteratur, 1987), 88-96.

104 Primary data from school boards $(1885,1891)$, H3aaa: 232, 288, Statistiska avdelningen, ED, RA. 
light on a variety of issues. It describes an elementary school system and teachers' working and living conditions that differ greatly from those that came to prevail in the twentieth century. This article has described school districts that owned not only schoolhouses, school yards and playgrounds, but also marshes, fields and meadows, plus cowsheds and bakehouses. Likewise, this article has shown how teachers in the Sundsvall region not only taught but also performed a wide variety of agricultural work such as ploughing and sowing, with tasks also including building and maintenance of outhouses.

Above all, this article has shed light on the funding of the expanding systems of mass schooling. Apart from central government grants and local taxation, teachers' allotted farms were a means of funding Swedish elementary schools in the first few decades after the School Act of 1842. They could contribute to be more than one fifth of an individual teacher's salary, and their contribution is roughly estimated at approximately one-tenth of the school districts' total payroll in the Sundsvall region in the 1860s. In addition, the allotted farms were inexpensive to acquire, often parcelled out from glebe land, and had reduced running costs, because the building, maintenance and agricultural work was carried out, often unpaid, by the teachers and their households.

Judging from this case study of the Sundsvall region, teachers' allotted farms thus appears as one of the factors that facilitated the expansion of mass schooling in Sweden, making the establishment of the elementary school system more affordable for the local school districts. Just like the low teachers' salaries in the Northern United States, which are believed to have contributed to the unusually high enrolment rates in these states, teachers' allotted farms supported the establishment of the Swedish school system by keeping down the taxation needed to maintain schools. ${ }^{105}$

105 The role of teachers' salaries in the US is discussed in Peter Lindert and Sun Go, "The Uneven Rise of American Public Schools to 1850," The Journal of Economic History 70, no. 1 (2010), 1-26. 
References

\section{Archival sources}

Riksarkivet (RA)

Ecklesiastikdepartementet.

Huvudarkivet

Cabinet acts, E1

Statistiska avdelningen

Primary data from school boards,

H3aaa

Statistical compilations, H3bd

Statistical compilations, H3abd

Brandförsäkringsverket

Fire insurances

Lantmäterimyndigheternas arkiv

Title deeds, ownership documents

Lantmäteristyrelsens arkiv (LMS)

Maps

Landsarkivet i Härnösand (HLA)

Domkapitlet i Härnösands stift Documents regarding elementary schools, G3b:5

Alnö kyrkoarkiv

Parish meeting minutes, K1

Attmar's kyrkoarkiv

Parish meeting minutes, K1

Indal kyrkoarkiv

Parish meeting minutes, K1

School board minutes, K4a
Hässjö kyrkoarkiv

Church meeting minutes, K2

Ljustorps kyrkoarkiv

Parish meeting minutes, K1

School board minutes, K4a

School district account books, L2a

Njurunda kyrkoarkiv

Parish meeting minutes, K1

School board minutes, K3a

School board minutes K4a

Selångers kyrkoarkiv

Parish- and schoolboard meeting minutes, K1

Skön's kyrkoarkiv

Parish meeting minutes, K1

Church meeting minutes, K2

Sättna kyrkoarkiv

Church meeting minutes, K1

Documents regarding the parish, $\mathrm{O} 2$

Timrå kyrkoarkiv

Parish meeting minutes, K1

School board minutes, K2

Tuna kyrkoarkiv

Parish meeting minutes, K1

School board minutes, K2

Ljustorps hembygdsförening

Images

\section{Printed sources}

Allm. Besv.- och Ekon.-Utsk. Betänk. N:o 64, in Bihang till Riksdagens protokoll 1853-1854, 8e samlingen.

BiSOS P. Bidrag till Sveriges officiella statistik. Undervisningsväsendet.

Daily Southern Cross.

Oldberg, Anders. Praktisk handbok i Pedagogik och methodik för Swenska folkunderwisningen. Stockholm: L. J. Hierta, 1846.

Peterson, Adam Crispin. "Folkskolebyggnader". Tidskrift för byggnadskonst och ingeniörvetenskap 6, (1864).

SFS 1842:19 Kongl. Maj:ts Nådiga Stadga angående folk-underwisningen i Riket; Gifwen Stockholms Slott den 18 Junii 1842.

SFS 1882:8, Kongl. Maj:ts förnyade nådiga stadga angående folkundervisningen i riket; gifven Stockholms slott den 20 Januari 1882. 
Svensk Läraretidning.

Tidskrift för byggnadskonst och ingeniörvetenskap.

Wagenius, S. H. "Berättelse om Folkskolorna inom Hernösands stift åren 18641866: Ångermanlands södra och östra kontrakt samt Medelpad”. In Berättelse om folkskolorna i riket för åren 1864-1866. Stockholm: Nordstedt \& söner, 1867.

Wiklund, Christina. Moster Wiklunds handbok. Sundsvall: Nils Wide, 2007.

Öfverintendentsembetet. Normalritningar till folkskolebyggnader jemte beskrifning. Stockholm: s.n., 1865.

Öfverintendentsembetet. Normalritningar till folkskolebyggnader jemte beskrifning: Andra omarbetade upplagan. Stockholm: s.n., 1878.

\section{Databases and electronic resources}

Folkmängd 1810-1990, Demographic Database (DDB), Umeå University.

Nationalencyclopedin < http://www.ne.se/>

$S A O B<$ http://g3.spraakdata.gu.se/saob/>

\section{Literature}

Andersson, Inger. Läsning och skrivning: En analys av texter för den allmänna läsoch skrivundervisningen 1842-1982. Umeå: Umeå universitet, 1986.

Anttila, Erkko and Ari Väänänen. "Rural Schoolteachers and the Pressures of Community Life: Local and Cosmopolitan Coping Strategies in Mid-Twentieth-Century Finland." History of Education 42, no. 2 (2013), 182-203.

Aquilonius, Klas. Svenska folkskolans historia: Del 2. Det svenska folkundervisningsväsendet 1809-1860. Stockholm: Albert Bonniers förlag, 1942.

Betänkande angående förändring av extra provinsialläkardistrikt till ordinarie samt ordnande av bostadsfrågan för provinsialläkare å landsbygden ävensom rörande åtgärder för avhjälpande av den inom de norrländska länen rådande läkarbristen m. m. Stockholm: Nord. bokh., 1921.

Boli, John. New Citizens for a New Society: The Institutional Origins of Mass Schooling in Sweden. Oxford: Pergamon, 1989.

Brühwiler, Ingrid. Finanzierung des Bildungswesens um 1800 in der Helvetischen Republik. Darstellung verschiedener Akteure sowie deren Einflussfaktoren und Wirkungen auf die wirtschaftliche Grundlage der Schule anhand ausgewählter Gemeinden und Städte in der Helvetischen Republik. Luxembourg: Université du Luxembourg, 2012a.

Brühwiler, Ingrid. ”Teachers' Salaries in the Helvetic Republic, c. 1800." In History of Schooling: Politics and Local Practice, edited by Carla Aubry and Johannes Westberg, 68-89. Frankfurt am Main: Peter Lang, 2012b.

Carter, Susan B. "Occupational Segregation, Teachers' Wages, and American Economic Growth." The Journal of Economic History 46, no. 2 (1986), 373-83.

Cederlöf, Olle. "Indelningsverkets militära torp och boställen." Meddelande XXXVI Armémuseum 1975-76 (1976), 53-85.

Day, C. R. "The Rustic Man: The Rural Schoolmaster in Nineteenth-Century France." Comparative Studies in Society and History 25, no. 1 (1983), 26-49.

Florin, Christina. Kampen om katedern: Feminiserings- och professionaliseringsprocessen inom den svenska folkskolans lärarkåren 1860-1906. Umeå: Almqvist \& Wiksell International, 1987. 
Fregert, Klas and Roger Gustafsson. "Fiscal Statistics for Sweden 1719-2003." Research in Economic History 25, no. 1 (2008), 169-223.

Gadd, Carl-Johan. "The Agricultural Revolution in Sweden 1700-1870." In The Agrarian History of Sweden: 4000 BC to AD 2000, edited by Janken Myrdal and Mats Morell, 118-64. Lund: Nordic Academic Press, 2011.

Gerhardsson, Björn. "Boställen och karaktärshus. Något om boställssystemet i Örebro län och dess avveckling under 1800-talet." In Från bergslag och bondebygd 1997, edited by Lars Skoghäll, 69-102. Örebro: Årsbok för Örebro läns hembygdsförbund, 1997.

Gräslund Berg, Elisabeth. Till prästens bruk och nytta: Jord till prästgårdar i Sverige under medeltid och tidigmodern tid. Stockholm: Stockholms universitet, 2004.

Hedin, Sven. ed., Ljustorp förr och nu: Bygd och människor. Del 1: Seder och bruk. Ljustorp: Sveriges pensionärsförbund, 1990.

Hofstedt, Lars, Viktor Fredriksson, and Sigurd Paradis. Svenska folkskolans historia. Del 5. Det svenska folkundervisningsväsendet 1920-1942. Stockholm: 1950.

Hultén, Magnus. Naturens kanon: Formering och förändring av innehållet i folkskolans och grundskolans naturvetenskap 1842-2007. Stockholm: Stockholms universitet, 2008.

Jacobsson, Benny and Maria Ågren. eds., Levebröd. vad vet vi om tidigmodern könsarbetsdelning? Uppsala: Swedish Science Press, 2011.

Johansson, Egil. "The History of Literacy in Sweden." In Understanding Literacy in its Historical Contexts: Socio-Cultural History and the Legacy of Egil Johansson, edited by Harvey J. Graff, Alison Mackinnon, Bengt Sandin and Ian Winchester, 28-59. Lund: Nordic Academic Press, 2009.

Johansson, Ulla. Att skolas för hemmet: Trädgårdsskötsel, slöjd, huslig ekonomi och nykterhetsundervisning $i$ den svenska folkskolan 1842-1919 med exempel frän Sköns församling. Umeå: Umeå universitet, 1987.

Jörberg, Lennart. A History of Prices in Sweden 1732-1914. Volume 1: Sources, Methods, Tables. Lund: Gleerup, 1972.

Kaestle, Carl F. and Maris A. Vinovskis. Education and Social Change in Nineteenth-Century Massachusetts. Cambridge: Cambridge University Press, 1980.

Klose, Gunilla. Folkundervisningens finansiering före 1842. Uppsala: SEC, Uppsala universitet, 2011.

Krantz, Olle. Historiska nationalräkenskaper för Sverige: Offentlig verksamhet 18001980. Lund: Studentlitteratur, 1987.

Kristenson, Hjördis. Skolhuset: Idé och form. Lund: Signum, 2005.

Kumm, Elfred. Indelt soldat och rotebonde. Stockholm: LT, 1989.

Lindert, Peter. Growing Public: Social Spending and Economic Growth since the Eighteenth Century Vol. 1 The Story. Cambridge: Cambridge University Press, 2004.

Lindert, Peter and Sun Go. "The Uneven Rise of American Public Schools to 1850." The Journal of Economic History 70, no. 1 (2010), 1-26.

Lindström, Jonas. Distribution and Differences: Stratification and the System of Reproduction in a Swedish peasant community 1620-1820. Uppsala: Acta Universitatis Upsaliensis, 2008.

Ljungberg, Jonas and Anders Nilsson. "Human Capital and Economic Growth: Sweden 1870-2000." Cliometrica 3, no. 1 (2009), 71-95.

Magnusson, Lars. An Economic History of Sweden. London: Routledge, 2000. 
Maynes, Mary Jo. Schooling for the People: Comparative Local Studies of Schooling History in France and Germany, 1750-1850. New York \& London: Holmes \& Meier, 1985.

Mitch, David. "The Impact of Subsidies to Elementary Schooling on Enrolment Rates in Nineteenth-Century England." The Economic History Review 39, no. 3 (1986), 371-91.

Myrdal, Janken. "Betingsläror och arbetsåtgång i lantbruket." In Landbon, ladan och lagen och hägnaderna, arbetstiden och bygdelaget samt ytterligare 20 agrarhistoriska artiklar, edited by Anders Perlinge, 147-61. Stockholm: Kungl. Skogs- och lantbruksakademien, 1996.

Myrdal, Janken. "Source Pluralism as a Method of Historical Research." In Historical Knowledge: In Quest of Theory, Method and Evidence, edited by Susanna Hellman and Marjatta Rahikainen, 155-89. Newcastle upon Tyne: Cambridge Scholars Publishing, 2012.

Ogilvie, Sheilagh C. A bitter living: Women, Markets, and Social Capital in Early Modern Germany. Oxford: Oxford University Press, 2003.

Petterson, Lars. Frihet, jämlikhet, egendom och Bentham: Utvecklingslinjer i svensk folkundervisning mellan feodalism och kapitalism, 1809-1860. Uppsala: Almqvist \& Wiksell International, 1992.

Schön, Lennart. "Västernorrland in the Middle of the Nineteenth Century: A Study in the Transition from Small-scale to Capitalistic Production." Economy and History 15 (1972), 83-111.

Stake, Robert E. The Art of Case Study Research. Thousand Oaks, CA: Sage, 1995.

Stephens, W. B. Education, Literacy and Society, 1830-70: The Geography of Diversity in Provincial England. Manchester: Manchester University Press, 1987.

Svala, Catharina. Från ladu-gård till djur-stall: Ekonomibyggnader under 250 år. Lund: Kungl. Skogs- och Lantbruksakademien, 1993.

Tedebrand, Lars-Göran. Västernorrland och Nordamerika 1875-1913: Utvandring och återinvandring. Stockholm: Läromedelsförlaget, 1972.

Tedebrand, Lars-Göran. Selånger: En sockens historia. Sundsvall: Selångers församling, 1983.

Thisner, Fredrik. Indelta inkomster: En studie av det militära löneindelnlingsverket 1721-1833. Uppsala: Acta Universitatis Upsaliensis, 2014.

Thulin, Gabriel. Redogörelse för de ecklesiastika boställena 6 vol. Stockholm: s.n., 1904-1929.

Thulin, Gabriel. Redogörelse för de ecklesiastika boställena: Del 2. Västernorrlands län. Stockholm: s.n., 1906.

Thulin, Gabriel. Utredning angående klockar-, organist- och kantors(kyrkosångar) befattningarna. Avdelning 1. Stockholm: s.n., 1919.

Thunman, Dan. Sveriges fyrplatser: En bebyggelsehistorisk dokumentation av f.d. bemannade fyrplatser anlagda under Lotsverkets tid. Norrköping \& Stockholm: Sjöfartsverket \& Riksantikvarieämbetet, 2000.

Ulväng, Göran. Hus och gård i förändring: Uppländska herrgårdar, boställen och bondgårdar under 1700- och 1800-talens agrara revolution. Hedemora: Gidlund, 2004.

Ulväng, Göran. ”Indelningsverkets militära boställen: Vad vet vi egentligen?.” Militärhistorisk tidskrift (2002), 173-212. 
Westberg, Johannes. Att bygga ett skolväsende: Folkskolans förutsättningar och framväxt 1840-1900. Lund: Nordic Academic Press, 2014.

Westberg, Johannes. "How Much did a Swedish Schoolhouse Cost to Build? Rewriting the History of Nineteenth Century Rural Schoolhouses." Scandinavian Journal of History 39, no. 4 (2014), 448-71.

Westberg, Johannes. "Stimulus or Impediment? The Impact of Matching Grants on the Funding of Elementary Schools in Sweden during the Nineteenth Century." History of Education 41, no. 1 (2013), 1-22.

Åman, Anders. "Inledning till skol-arkitekturen: Om Uppsala läroverk och svenskt skolhusbyggande i de stora undervisningsreformernas spår." Upplands nations årsskrift 25 (1962), 5-35. 